\title{
Lifestyle related to health and quality of life of girls at puberty in light of the KIDSCREEN-52 Questionnaire
}

\section{Styl życia związany ze zdrowiem i jakościa życia dziewcząt w okresie dojrzewania w świetle kwestionariusza KIDSCREEN-52}

\author{
Grażyna Nowak-Starz, Ewa Zięba \\ Department of Developmental Age Research, Institute of Public Health, Faculty of Health Sciences, Jan Kochanowski University, Kielce, \\ Poland \\ Head of the Department: Prof. JKU Grażyna Nowak-Starz MD, PhD
}

Medical Studies/Studia Medyczne 2017; 33 (2): 117-126

DOI: https://doi.org/10.5114/ms.2017.68705

Key words: health-related quality of life, KIDSCREEN-52.

Słowa kluczowe: jakość życia związana ze zdrowiem, KIDSCREEN-52.

\begin{abstract}
Introduction: The lifestyle of every human being, to a large extent, determines their health. Whatever young individuals do in their adult lives is extremely important for themselves and the next generations.

Aim of the research: To investigate the relationship between health-related lifestyle and the quality of life of girls in light of the KIDSCREEN-52 questionnaire.

Material and methods: The study involved 122 girls with menstrual disorders from rural and urban areas and 240 girls without any health or developmental disorders. It was conducted on patients of the Public Gynaecological Clinic for Girls in Kielce and girls attending primary and middle schools. A diagnostic survey was used including the following research tools: KIDSCREEN-52 questionnaire, authors' survey, body mass index, and Rohrer Index.

Results: The quality of life and health of girls with menstrual disorders (group I) and girls without any health or development disorders (group II) both from rural and urban areas was assessed. Taking into account variables such as age and the living environment, it was stated that younger girls (13-14 years old) from groups I and II generally perceive their health as worse $(p<0.001)$. Whereas, among older girls in both groups I and II (15-16 years old), a larger percentage of respondents perceive themselves in a positive way, which results in higher self-assessment in health.

Conclusions: The application of subjective health indicators in the assessment of quality of life relating to adolescence allows us to determine disease and malpractice in the care of the population in developmental age.
\end{abstract}

\section{Streszczenie}

Wprowadzenie: Styl życia każdego człowieka w dużym stopniu determinuje jego zdrowie. To, co młody człowiek wniesie w swoje dorosłe życie, jest niezwykle ważne dla niego samego i następnych pokoleń.

Cel pracy: Zbadanie związku pomiędzy stylem życia związanym ze zdrowiem a jakością życia dziewcząt w świetle kwestionariusza KIDSCREEN-52.

Materiał i metody: Przebadano 122 dziewczęta ze środowiska miejskiego i wiejskiego z zaburzeniami miesiączkowania oraz 240 dziewcząt bez zaburzeń w stanie zdrowia i rozwoju. Badanie przeprowadzono u pacjentek Publicznej Poradni Ginekologicznej dla Dziewcząt w Kielcach oraz dziewcząt uczęszczających do szkół podstawowych oraz gimnazjum. W badaniach zastosowano metodę sondażu diagnostycznego oraz następujące narzędzia badawcze: kwestionariusz KIDSCREEN-52, ankietę własnej konstrukcji, wskaźnik masy ciała oraz wskaźnik Rohrera.

Wyniki: Zbadano jakość życia i stan zdrowia dziewcząt z zaburzeniami miesiączkowania (grupa I) oraz dziewcząt bez zaburzeń w stanie zdrowia i rozwoju (grupa II) zarówno ze środowiska miejskiego, jak i wiejskiego. Po uwzględnieniu takich zmiennych, jak wiek badanych oraz środowisko zamieszkania, stwierdzono, że dziewczęta młodsze (13-14 lat) z grupy I i II ogólnie gorzej postrzegają własne zdrowie $(p<0.001)$. Wraz z wiekiem w obu badanych grupach I i II (15-16 lat) obserwuje się większy odsetek dziewcząt, które postrzegają pozytywnie własną osobę, co przekłada się na wzrost ich samooceny dotyczącej zdrowia.

Wnioski: Zastosowanie subiektywnych wskaźników zdrowia w ocenie jakości życia związanej z okresem adolescencji pozwala określić choroby i zaniedbania w opiece nad populacją w wieku rozwojowym. 


\section{Introduction}

The World Health Organisation defines health as a subjective "state of complete physical, mental, and social well-being, and not merely the absence of disease or infirmity" $[1,2]$.

The lifestyle of every human being, to a large extent, determines their health. Many disorders that occur in children and adolescents have a behavioural background. Whatever a young person brings into their adult life is extremely important to him/her and the next generations.

Health in adolescence, according to the WHO, is the wellbeing and ability to exploit fully the potential for development in the following dimensions: somatic, mental, social, and spiritual, which is fostered by sensitivity to sensory stimuli, as well as one's and others' emotional states. Due to their sensitivity adolescents become susceptible to a number of risk factors [1].

Health behaviours include pro-health activities, i.e. conducive to health, which involve physical activity, balanced diet, personal hygiene, coping with stress, proper social contact, preventive medical examinations, and anti-health behaviours, i.e. health hazards (tobacco smoking, alcohol, psychogenic substances, casual sexual contact).

In contemporary research on health, attention is focused on the use of subjective measures, viz. selfassessment. It is conducted by the respondents themselves, not professionals, which is the case in objective health assessment. Attempts have been made to continue using various tools for assessing subjective health.

The studies of subjective health of adolescents, including common ailments, may be useful for these reasons [3]:

- early identification of risk groups. The results of the foregoing research show that health self-assessment is relatively "stable", e.g. it is characteristic for adolescent depression and many psychosomatic symptoms to persist in youth and adulthood. The identification of these symptoms makes early prevention possible.

- facilitation of learning and understanding of factors that predispose adolescents to develop health problems and health-hazardous behaviours, e.g. negative self-assessment of health related to depression, incidence of traumas, tobacco smoking.

- building strategies to prevent various health, social, and school problems, focusing on developing coping skills which adolescents will continue to use in their adult life. It was shown that adolescents experience ailments such as headaches, sleep disorders, and often difficulties in learning.

The developmental age of girls is of particular importance when predicting the occurrence of puberty and final body height, and for determining suitabil- ity for a profession or determining the indications (or contraindications) for practicing various sports. They can also be applied in psychological studies.

The maturation process in girls usually begins at the age of $8.5-13.5$ years. At puberty each somatic feature exhibits intensive growth. The changes relating to length and width features occur in a specific order.

During adolescence changes that are observed in girls concern the formation of hypodermic fat. The thickness of skin and fat fold in girls around 8 years of age shows a tendency to grow [4].

\section{Material and methods}

The material for the study was from the research conducted by a team led by a nurse - Prof. Grażyna Nowak-Starz - the head of the scientific research (no. 095S) entitled "Risks of child and adolescent health and development in the Swietokrzyskie region", which was part of a research project (2.01.2009-31.12.2014) commissioned by the Ministry of Science and Higher Education in Poland. The research was conducted at the Institute of Development Studies at the Faculty of Health Sciences of Jan Kochanowski University in Kielce, Poland. The data is a selected part of the analyses of the research, in which the area connected with quality of life was carried out by a midwife - Ewa Zięba, PhD. The research was conducted during 2009/2010; 122 girls with menstruation disorders and 240 girls without disorders in the state of health and development were examined. These were girls from primary and middle schools in the Swietokrzyskie region, which is part of the so-called "Eastern region" of Poland, with an impoverished social and economic infrastructure compared to other regions of the country.

The first stage was a deliberate selection of a group of girls with menstruation disorders (group I); these were the patients of the Public Gynaecological Clinic for Girls at the Gynaecology-Obstetrics Hospital in Kielce. Taking into consideration the objective that was set and the fact that the research is not considered in a clinical context but that of an assessment of lifestyle and the quality of life in good health, the term "menstruation disorders" was defined as a high frequency of occurrence of temporary menstruation disorders during the formation of the hypothalamicpituitary axis at age 13-16 years. Hence the result is a group of girls, uniform in terms of menstruation disorder aetiology, in which no cases of explicit and profound endocrine disorders such as hypergonadotropic or hypogonadotropic hypogonadism were stated according to the performed hormonal examinations. A homogenous group of girls without menstruation disorders (group II) was formed as material for comparison. The method of group sampling with stratification according to school and class type was used in the research. A list of primary and middle schools located in the Swietokrzyskie region was 
created. Two primary and two middle schools were drawn out at random, and a sampling within the class was made. Altogether, 14 classes with seven classes from each type of school were drawn out at random, and girls, aged 13 to 16 years, who had menstruation were selected from each class. The age of menarche was determined using the "status quo" method. The data used was the precise age of the examined and an answer to a yes/no question whether menstruation was present.

Next, the health and the lifestyle of the subjects were assessed. A medical and nursing assessment was performed for the state of health. Secondary statistical materials such as disease history and laboratory examination results provided information on the girls' disorders.

The preferred lifestyle was determined from the diagnostic poll and questionnaires. As lifestyle is not a homogeneous term and comprises health behaviour, attitudes, actions, and a person's general life philosophy, special attention was devoted to health behaviour. The Polish version of the KIDSCREEN-52 Health-Related Quality of Life Questionnaire for Children and Young People created by the KIDSCREEN GROUP EUROPE was used to study the quality of life. The KIDSCREEN international scientific project was carried out simultaneously in 13 European counties, at the request of the European Commission. In Poland, the Department of Epidemiology at the Institute of Mother and Child in Warsaw was engaged in the research, in cooperation with the Faculty of Education at the University of Warsaw. The international coordinator for the project is Prof. Urlike Ravens-Sieberer the national coordinator of the project in Poland is Joanna Mazur, MD PhD. The pilot research in Poland in 2003 did not involve the Swietokrzyskie region.

The KIDSCREEN family questionnaires were devised in 13 countries and in 10 language versions. They belong to measurement tools for the quality of life connected with the health of children and adolescents aged 8 to 18 years. Ultimately, three variants of the KIDSCREEN questionnaire were created, each having a version for the child or for the parent/guardian answering in their name.

The full version, containing 52 questions (KIDSCREEN-52), which determines the quality of life profile taking into account 10 sub-areas, was used in the authors' research. One dimension in the KIDSCREEN-52 questionnaire is concerned with physical health, and three areas are attributed to mental health, i.e.: mental well-being, moods and emotions, and self-perception. Five dimensions deal with social functioning, including the relation with parents and life at home, the relation with peers and social support, independence, the school environment, and social acceptance (lack of harassment). The last dimension concerns financial resources.
A rule of answering from the perspective of the previous week was adopted in the questionnaire. Answers to the questions are given according to standardised five-level categories regarding frequency (never, rarely, quite often, often, and always) or intensity (not at all, a bit, mildly, very, immensely). A positive orientation was assumed in most of the questions, implying that the first answer is the most negative and the last is the most positive. Questions marked with an asterisk $\left(^{*}\right)$ have an opposite orientation and require an inverted coding.

\section{Results}

\section{Lifestyle and health behaviour}

The study presents an analysis of selected behaviours comprising the lifestyle of girls with menstruation disorders against the background of their healthy peers, including physical activity, diet and nutrition, adhering to road safety rules, oral health, attitudes towards alcohol and nicotine addiction, as well as indicators of health and well-being.

- Physical activity - a distinct downward tendency along with increasing age was observed. It is unfavourable due to a transfer of activity patterns from adolescence to adulthood. There is too little physical exercise during free time (36\% of girls aged 13-14 years and $30 \%$ of girls aged $15-16$ years from group II exercised once a week; similarly, $26 \%$ of the examined aged 13-14 years and only 10\% aged 15-16 years exercised once a week in group I). Accordingly, 30\% of girls aged 13-14 years and 35\% of girls aged 15-16 years from group II spent only half an hour a week on physical exercise. The data in group I are even more unfavourable: $38.5 \%$ (aged 13-14 years) and $40.8 \%$ (aged $15-16$ years). Immobilisation was connected with watching television; an unfavourable tendency was noted taking into consideration the variable of age and menstruation disorders in the examined (35\% of healthy girls aged 13-14 years in group II and 40\% of those aged 15-16 years watched TV 2 to $3 \mathrm{~h}$ a day; similarly, the situation in group I with menstruation disorders reached the levels of $39.5 \%$ and $43 \%$, respectively. Moreover, it was found that as many as 35\% of girls aged 15-16 years from group I spent 1 to $3 \mathrm{~h}$ a week on computer games and surfing the Internet).

- Nutrition habits - deficiencies in consumption of essential products were noted, wherein this concerned girls from group II regardless of the age category (brown bread was consumed by merely $20 \%$ of those aged $13-14$ years and $24 \%$ by those aged 15-16 years in the group of healthy girls; similarly, raw vegetables were eaten by $27 \%$ and $21 \%$ of the examined, respectively; $63 \%$ and $27 \%$ of the examined consumed sweets and sweet carbonated beverages more often than once a day). In group I, in the 
age group of $13-14,18 \%$ consumed brown bread, $25.5 \%$ - raw vegetables, and $67 \%$ - sweets and sweet carbonated beverages; similarly, in the 15-16 age group, this was $16 \%, 23 \%$, and $66.5 \%$, respectively.

Oral hygiene - the girls showed deficiencies in attention to oral hygiene (of the girls from group II, $62 \%$ aged 13-14 years and 73\% aged 15-16 years brushed their teeth more often than once a day; this was 59\% and $65 \%$, respectively, in group I).

Furthermore, the following risky health behaviours with varying degrees of intensity were stated in the research:

- Not adhering to road safety rules - it was stated that whilst in a car 25\% aged $13-14$ years and $27 \%$ aged 15-16 years in group II sometimes or rarely use seatbelts; in group I, the results reached the levels of $26.5 \%$ and $28 \%$, respectively.

- Smoking tobacco - most probably as a result of the anti-smoking measures taken in recent years, and due to the headcount of the group, the data obtained indicates a significant percentage of nonsmoking girls (83\% and 89\% in the age categories of girls from group II and, similarly, $79 \%$ and $85 \%$ in group I of the examined). The remaining percentage of girls smoking cigarettes each day, both in the group of healthy girls and those with menstruation disorders, is a cause for concern.

- Alcohol consumption - similarly to the case of tobacco smoking, this poses a lesser problem than in other EU countries. Similar tendencies were observed in the authors' own research; it was found that $6 \%$ of girls aged $13-14$ years and $5 \%$ of girls

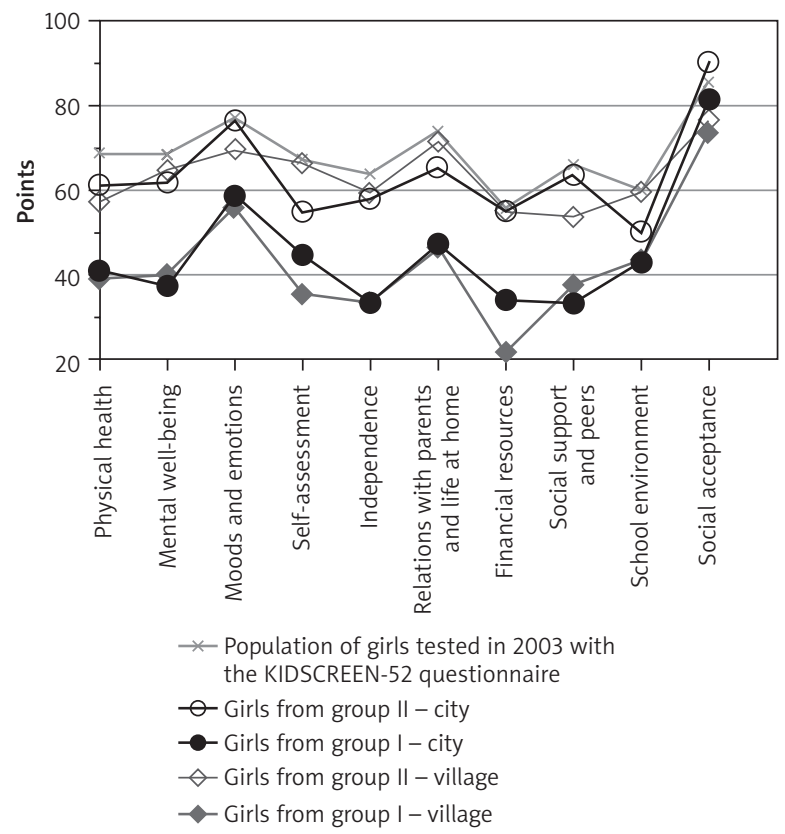

Figure 1 . The profile of the quality of life connected with the health of girls aged 13-14 years from groups I and Il from urban and rural environments aged 15-16 years from group II consumed alcohol once a week, whilst once a month $5 \%$ and $4.5 \%$, and $4 \%$ and $5 \%$, respectively, of the girls in the examined age categories. In group I, the results reached a more unfavourable level; $6.5 \%$ of the examined aged $13-$ 14 years and 7\% aged $15-16$ years consumed alcohol once a week, and $5.5 \%$ and $7.5 \%$ consumed it once a month, whilst $4.8 \%$ and $7.5 \%$, respectively, of the girls with menstruation disorders in the examined age categories consumed alcohol at least 2-3 times per week.

\section{The health-related quality of life}

The quality of life connected with the health of girls in group I and II in light of the KIDSCREEN-52 questionnaire in terms of particular dimensions.

As mentioned, the environment variable, which differentiated the attitudes of girls, was also taken into consideration in the analysis regarding the quality of life connected with the health of girls with menstruation disorders (group I), and those without health and development disorders (group II) (Figure 1).

The comparison of girls aged 13-14 years (group I) from urban and rural environments indicates a gradual decline in the quality of life connected with health in relation to the pilot studies of the population of girls in 2003 using KIDSCREEN-52. The dimensions of social acceptance are the sole exception, where mean indexes of the quality of life are on the rise, whereas in the financial resources dimension indexes of the quality of life are declining. The remaining dimensions of the KIDSCREEN-52 questionnaire are not significant, with a tendency to reach higher values in girls from the urban environment.

In turn, the comparison of girls aged 13-14 years from group II from urban and rural environments indicated a more positive assessment of the healthrelated quality of life of girls from the rural environment in the following dimensions: mental well-being, self-perception, independence, the relations with parents and life at home, and the school environment. Physical health, moods and emotions, social support among peers, and social acceptance are the remaining dimensions of the KIDSCREEN-52 questionnaire where much better results were noted in girls from the urban environment. In the financial resources dimension, the results were the same in both groups.

By comparing the obtained indexes in both groups with the results of the pilot study, it was revealed that the girls who live in the city were significantly below the norm with respect to the dimensions of self-perception and school environment. The remaining dimensions were close to the above-mentioned norm in both groups of girls (Figure 2).

Taking into consideration the age range of the participants, the same analyses were performed in the 15-16-year-old age group. A comparison of the groups 
of girls aged 15-16 years from group I from urban and rural environments indicated a gradual decline in the quality of life connected with health in relation to the pilot studies, with the following dimensions being the exception: moods and emotions, the school environment, and social acceptance, where the mean indexes of the quality of life are on the rise, whereas in the dimensions of self-perception and financial resources in girls from the rural environment the mean indexes of the quality of life were declining. The remaining dimensions of the KIDSCREEN-52 questionnaire were not significant, with a tendency to reach higher values in girls from the urban environment.

A comparison of the girls aged 15-16 years from group II from urban and rural environments indicates a more positive assessment of the health-related quality of life of the girls from the urban environment in the following dimensions: physical health, mental well-being, moods and emotions, independence, the relations with parents and life at home, financial resources, as well as in the dimensions of emotional support among peers and social acceptance. It was noted, however, that healthy girls from the urban environment have a significantly lower self-perception than the healthy girls from the rural environment. The remaining dimensions from the KIDSCREEN-52 questionnaire were assessed significantly lower by the girls from the rural environment than by the girls from the urban environment.

By comparing the indexes obtained in group II of the girls from urban and rural environments with the results of the pilot studies of girls aged 15-16 years in 2003 according to the KIDSCREEN-52 questionnaire, it was revealed that the girls from the rural environment have a very positive self-assessment in two of the dimensions, i.e. moods and emotions, and selfperception. Whereas girls from the urban environment had a very positive self-assessment and exceeded the results of the research on girls from 2003 in the following dimensions: mental well-being, moods and emotions, independence, the relations with parents and life at home, financial resources, as well as social support and peers, and social acceptance.

In later analysis, it was observed that girls from group I from urban and rural environments in the 13-14-year-old age groups, as well as in the 15-16-year-old age groups had worse starting results in the following dimensions: physical health, mental well-being, moods and emotions, self-perception, the relations with parents and life at home, and independence, as well as in the dimensions of financial resources and social support.

It was observed that the assessment of the quality of life improved along with age for girls from group I from the rural environment in the following dimensions: physical health, mental well-being, moods and emotions, independence, the relations with parents and school environment, financial resources, and

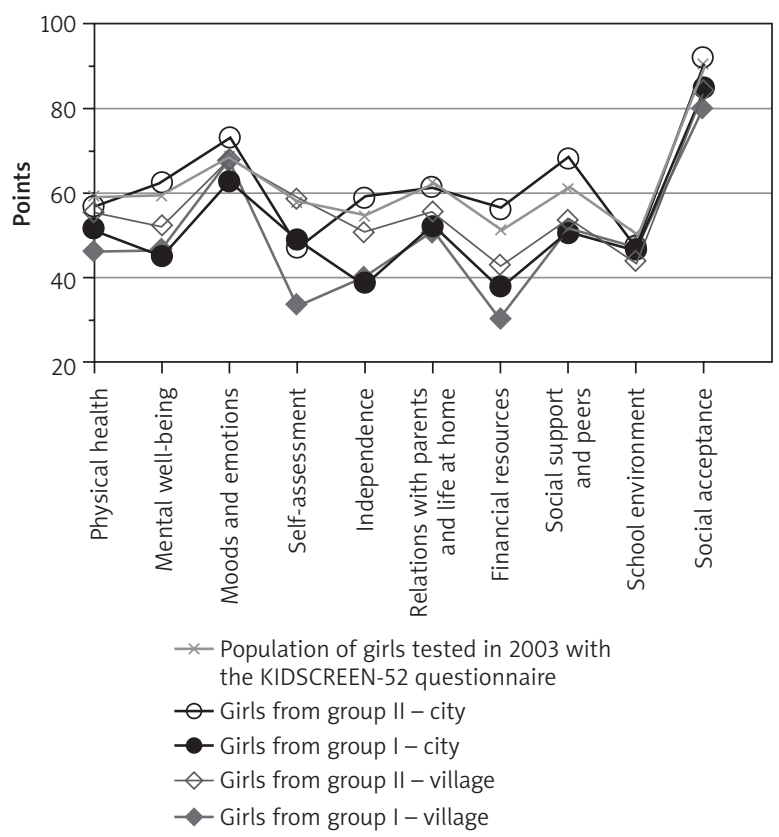

Figure 2 . The profile of the quality of life connected with the health of girls aged 15-16 years from groups I and II from urban and rural environments

social support and acceptance. Whereas the results in the self-perception dimension distinctly dropped along with increasing age, which is very disturbing. Conversely, the girls from group I from the urban environment obtained significantly better results in the dimension of self-perception, and additionally, along with age their self-assessment improved.

Girls from group II (aged 13-14 and 15-16 years) from both of the environments had significantly better results than the girls from group I in the analysed dimensions of quality of life. However, in the dimensions of physical health, mental well-being, self-perception, independence, the relations with parents and life at home, financial resources, and the school environment worse starting results were noted for the girls from group II from the rural environment, who, along with age, obtained worse results in the analysed dimensions of the quality of life. Better results were noted in this group in the dimensions of moods and emotions and social acceptance. Older girls from group II from the urban environment obtained better results in the following dimensions: mental wellbeing, independence, financial resources, social support, and social acceptance, which indicates an ever more positive assessment of the quality of life. However, along with age the following dimensions results worsened: physical health, moods and emotions, selfperception, the relations with parents, and the school environment.

Consistent with certain psychological theories, the health-related quality of life diminished in a specific way along with the increasing age of the girls. Whilst 
maturing, girls face physical and social changes and have to adapt to them. As a result of hormonal changes in girls, physiological processes may take an unusual course, which may lead to an impaired assessment of the health-related quality of life. Girls of around thirteen years of age find themselves in a difficult situation in terms of a subjective understanding of health and the quality of life. Menarche, menstruation disorders, a predominance of stressful events in life, and particular coping mechanisms all add to this. All of those elements may deteriorate mental well-being.

In the authors' research regarding girls from Group I from both environments, as well as girls from group II from the urban environment, the quality of life improves in the dimensions of finance and social acceptance. As may be observed, adolescents are becoming ever more independent of their parents, so social acceptance is improving greatly.

\section{Correlation between the KIDSCREEN-52 dimensions and the age of the girls from groups I and II taking part in the study}

An evaluation of the mutual relationships was made, and the most relationships were found between the dimensions of quality of life connected with health, and the age of the participants.

The most significant correlation in group I in the 13-14-year-old age range was noted between mental well-being and physical health (0.666), and in the relation of moods and emotions and mental well-being (0.771). This indicates that a more positive assessment of quality of life is connected with conscious and responsible decisions in matters of one's own life in health. Whereas, in the category of social acceptance and the relations with parents and life at home, its relationship was only confirmed with a 0.090 correlation coefficient.

In turn, based on the analysis of the correlation of results for girls from group I, aged 15-16 years, it was found that the better the physical health, the better the mental well-being (0.745), and better mental wellbeing influences the improvement of moods and emotions (0.691), which has an effect on the good relations with parents and life at home (0.513). Whereas, the correlation coefficient between the dimension of selfperception and the dimension of social support and peers assumes negative values $(-0.204)$, which may indicate that the worse the acceptance among peers, the (far) worse the self-assessment. By analysing the correlations in group I, it can be seen that girls aged 15-16 years assessed their lives in the most positive way. The dimension of social acceptance is an exception, where the mean indexes of the quality of life increase along with age.

In group II of girls aged 13-14 years, the most significant negative correlations were noted between self-perception and social acceptance $(-0.009)$, and in the dimensions of social acceptance and the school environment $(-0.243)$, which indicates that the lower the acceptance in the environment in which the girl grows up, the more her self-assessment deteriorates. Negative correlations were noted in girls from group II, aged 15-16 years, between the dimensions of moods and emotions and self-perception (-0.018), and between the dimension concerning social support among peers and self-assessment $(-0.020)$, as well as between social acceptance and the relations with parents and life at home $(-0.023)$, and between social acceptance and financial resources (-0.052). Detailed data are presented in Tables 1 and 2.

\section{Discussion}

The KIDSCREEN project was carried out in Poland as well as in 13 other European countries in the years 2003-2004 as part of the Fifth Framework Programme of the EU. The obtained research results reveal relationships between the state of health, the lifestyle, the social and economic situation of girls and their families, and the indexes of the quality of life according to the KIDSCREEN questionnaire [5, 6].

The intention of the research was to provide valuable information for people who are responsible for the health condition of children and adolescents, to facilitate the atmosphere of diligent professional work, and to gain knowledge about health and diagnostic skills.

Children are our investment in the society of tomorrow. Their health and the way in which they are brought up from the period of adolescence to adulthood will influence the well-being and stability of the countries in the region of Europe in decades to come $[7,8]$.

The period of adolescence is the final phase of childhood and the beginning of adulthood. In this short span of time radical mental and physical changes take place, which enable an individual to undertake new tasks and social roles appropriate for an adult [9].

During this time, the health behaviours that young people will carry over into their adult life, and that may be the factors of health risks, are also shaped. The negative health indexes are not as high at this age as they are in adults. Therefore, the skills, knowledge, beliefs, and attitudes towards positive measures of health such as physical development or health-related quality of life in adolescence will determine the lifestyle and health later on in adulthood [10].

In the authors' research on the preferred lifestyle of girls with menstruation disorders compared to their healthy peers, a significantly greater number of negative health behaviours were observed, such as abnormalities in nutrition, little physical activity, insufficiencies in attention to oral hygiene, non-compliance with road safety, smoking, and the phenomenon of alcoholism. 
Table 1. Correlation relationships between the KIDSCREEN-52 dimensions of girls aged 13-14 years from group I and II

\begin{tabular}{|c|c|c|c|c|c|c|c|c|c|c|c|}
\hline 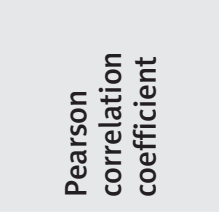 & $\begin{array}{l}\text { 은 } \\
\text { ㅇํㄴ }\end{array}$ & 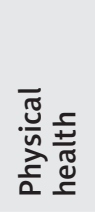 & 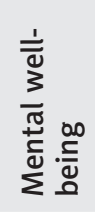 & 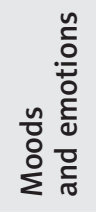 & 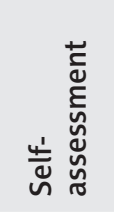 & 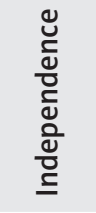 & 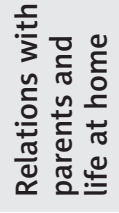 & 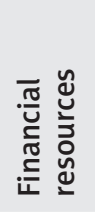 & 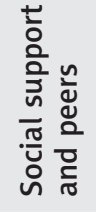 & 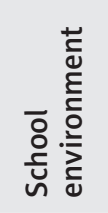 & 党 \\
\hline \multirow[t]{2}{*}{ Physical health } & I & & 0.666 & 0.458 & 0.594 & 0.377 & 0.300 & 0.121 & 0.256 & 0.536 & 0.439 \\
\hline & II & & 0.556 & 0.107 & 0.283 & 0.352 & 0.265 & 0.430 & 0.414 & 0.310 & 0.028 \\
\hline \multirow{2}{*}{$\begin{array}{l}\text { Mental } \\
\text { well-being }\end{array}$} & 1 & 0.666 & & 0.711 & 0.605 & 0.542 & 0.554 & 0.224 & 0.575 & 0.556 & 0.478 \\
\hline & II & 0.556 & & 0.413 & 0.474 & 0.533 & 0.515 & 0.366 & 0.339 & 0.545 & 0.056 \\
\hline \multirow{2}{*}{$\begin{array}{l}\text { Moods and } \\
\text { emotions }\end{array}$} & 1 & 0.458 & 0.711 & & 0.528 & 0.424 & 0.464 & 0.201 & 0.437 & 0.469 & 0.398 \\
\hline & II & 0.107 & 0.413 & & 0.416 & 0.147 & 0.312 & 0.086 & 0.044 & 0.210 & 0.361 \\
\hline \multirow{2}{*}{$\begin{array}{l}\text { Self- } \\
\text { assessment }\end{array}$} & I & 0.594 & 0.605 & 0.528 & & 0.302 & 0.352 & 0.465 & 0.387 & 0.405 & 0.512 \\
\hline & II & 0.283 & 0.474 & 0.416 & & 0.347 & 0.462 & 0.276 & 0.064 & 0.463 & -0.009 \\
\hline \multirow[t]{2}{*}{ Independence } & 1 & 0.377 & 0.542 & 0.424 & 0.302 & & 0.462 & 0.119 & 0.608 & 0.307 & 0.143 \\
\hline & II & 0.352 & 0.533 & 0.147 & 0.347 & & 0.554 & 0.514 & 0.472 & 0.357 & 0.063 \\
\hline \multirow{2}{*}{$\begin{array}{l}\text { Relations with } \\
\text { parents and } \\
\text { life at home }\end{array}$} & 1 & 0.300 & 0.554 & 0.464 & 0.352 & 0.462 & & 0.531 & 0.339 & 0.390 & 0.090 \\
\hline & II & 0.265 & 0.515 & 0.312 & 0.462 & 0.554 & & 0.559 & 0.258 & 0.624 & 0.047 \\
\hline \multirow{2}{*}{$\begin{array}{l}\text { Financial } \\
\text { resources }\end{array}$} & 1 & 0.121 & 0.224 & 0.201 & 0.465 & 0.119 & 0.531 & & 0.250 & 0.167 & 0.168 \\
\hline & II & 0.430 & 0.366 & 0.086 & 0.276 & 0.514 & 0.559 & & 0.522 & 0.443 & 0.103 \\
\hline \multirow{2}{*}{$\begin{array}{l}\text { Social support } \\
\text { and peers }\end{array}$} & 1 & 0.256 & 0.575 & 0.437 & 0.387 & 0.608 & 0.339 & 0.250 & & 0.348 & 0.423 \\
\hline & II & 0.414 & 0.339 & 0.044 & 0.064 & 0.472 & 0.258 & 0.522 & & 0.231 & 0.270 \\
\hline \multirow{2}{*}{$\begin{array}{l}\text { School } \\
\text { environment }\end{array}$} & 1 & 0.536 & 0.556 & 0.469 & 0.405 & 0.307 & 0.390 & 0.167 & 0.348 & & 0.447 \\
\hline & II & 0.310 & 0.545 & 0.210 & 0.463 & 0.357 & 0.624 & 0.443 & 0.231 & & -0.243 \\
\hline \multirow{2}{*}{$\begin{array}{l}\text { Social } \\
\text { acceptance }\end{array}$} & 1 & 0.439 & 0.478 & 0.398 & 0.512 & 0.143 & 0.090 & 0.168 & 0.423 & 0.447 & \\
\hline & II & 0.028 & 0.056 & 0.361 & -0.009 & 0.063 & 0.047 & 0.103 & 0.270 & -0.243 & \\
\hline
\end{tabular}

Woynarowska, in her research using the HBSC (Health Behaviour in School-Aged Children 1997/98, 2001/2002, 2005/2006) questionnaires, found that girls with menstruation disorders, in comparison to their peers who reached puberty normally or later, assessed their state of health as worse, have significantly more frequently reported numerous ailments or negative emotional states and gone on a diet without excessive body mass. No differences were stated between the groups in terms of satisfaction with life. Girls who menstruated earlier and had menstruation disorders, smoked tobacco regularly and more often, abused alcohol, and had sexual intercourse. In the aforementioned aspect, early puberty is a risk factor for the health of girls $[10,11]$. In the authors' own analyses, girls with menstruation disorders, originating from urban and rural environments, perceived their health and well-being in a negative way. This detriment in the girls' well-being was caused by menstruation disorders during the period of adolescence. It can be stated that they are a group at risk when it comes to the occurrence of various disorders in years to come, especially those of mental and physical health. Unfortunately, due to the use of two different research tools (HBSC - B. Woynarowska, KIDSCREEN-52 - J. Mazur), the comparison of results can only be a general one.

In the comparisons in European health reports 2005: public health action for healthier children and populations and WHO Europe 2005, and the European health reports published in later years (last in 2011), as well as in the "Flash Eurobarometer No. 233-Young people and drugs" report, young people in Poland have assessed the risk of negative health behaviours on the level of the EU average; however, there are no references to groups of girls with menstruation disorders in these documents.

The isolation of subjective aspects of physical and mental health leads to the term "quality of life" (QoL). Because quality of life depends on many factors (including the financial situation, social acceptance, family life, etc.), it was defined as health-related quality of life (HRQL). Thus, health-related quality of life 
Table 2. Correlation between the KIDSCREEN-52 dimensions of girls aged 15-16 years from group I and II

\begin{tabular}{|c|c|c|c|c|c|c|c|c|c|c|c|}
\hline 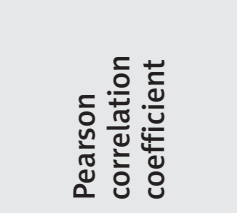 & $\begin{array}{l}\text { 온 } \\
\text { ํํㄴ }\end{array}$ & 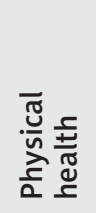 & 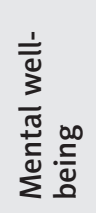 & 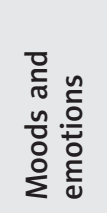 & 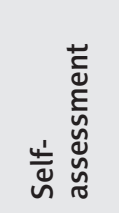 & 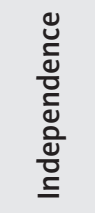 & 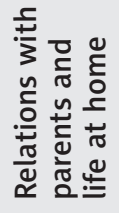 & 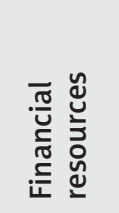 & 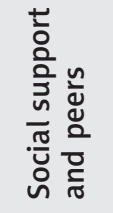 & 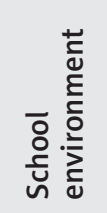 & 党 \\
\hline \multirow[t]{2}{*}{ Physical health } & I & & 0.745 & 0.485 & 0.407 & 0.339 & 0.580 & 0.195 & 0.165 & 0.319 & 0.343 \\
\hline & II & & 0.517 & 0.183 & 0.171 & 0.456 & 0.356 & 0.354 & 0.433 & 0.442 & 0.003 \\
\hline \multirow{2}{*}{$\begin{array}{l}\text { Mental well- } \\
\text { being }\end{array}$} & I & 0.745 & & 0.691 & 0.353 & 0.453 & 0.698 & 0.154 & 0.416 & 0.410 & 0.271 \\
\hline & II & 0.517 & & 0.551 & 0.034 & 0.519 & 0.554 & 0.450 & 0.607 & 0.559 & 0.043 \\
\hline \multirow{2}{*}{$\begin{array}{l}\text { Moods and } \\
\text { emotions }\end{array}$} & 1 & 0.485 & 0.691 & & 0.162 & 0.369 & 0.513 & 0.018 & 0.501 & 0.376 & 0.308 \\
\hline & II & 0.183 & 0.551 & & -0.018 & 0.226 & 0.330 & 0.117 & 0.161 & 0.223 & 0.367 \\
\hline \multirow[t]{2}{*}{ Self-assessment } & 1 & 0.407 & 0.353 & 0.162 & & 0.053 & 0.268 & 0.285 & -0.204 & 0.142 & 0.309 \\
\hline & II & 0.171 & 0.034 & -0.018 & & 0.060 & 0.101 & 0.266 & -0.020 & 0.028 & 0.021 \\
\hline \multirow[t]{2}{*}{ Independence } & I & 0.339 & 0.453 & 0.369 & 0.053 & & 0.342 & 0.283 & 0.600 & 0.362 & 0.242 \\
\hline & II & 0.456 & 0.519 & 0.226 & 0.060 & & 0.405 & 0.302 & 0.546 & 0.342 & 0.059 \\
\hline \multirow{2}{*}{$\begin{array}{l}\text { Relations with } \\
\text { parents and life } \\
\text { at home }\end{array}$} & 1 & 0.580 & 0.698 & 0.513 & 0.268 & 0.342 & & 0.393 & 0.469 & 0.492 & 0.335 \\
\hline & II & 0.356 & 0.554 & 0.330 & 0.101 & 0.405 & & 0.537 & 0.444 & 0.594 & -0.023 \\
\hline \multirow{2}{*}{$\begin{array}{l}\text { Financial } \\
\text { resources }\end{array}$} & I & 0.195 & 0.154 & 0.018 & 0.285 & 0.283 & 0.393 & & 0.333 & 0.346 & 0.221 \\
\hline & II & 0.354 & 0.450 & 0.117 & 0.266 & 0.302 & 0.537 & & 0.534 & 0.529 & -0.052 \\
\hline \multirow{2}{*}{$\begin{array}{l}\text { Social support } \\
\text { and peers }\end{array}$} & 1 & 0.165 & 0.416 & 0.501 & -0.204 & 0.600 & 0.469 & 0.333 & & 0.459 & 0.224 \\
\hline & II & 0.433 & 0.607 & 0.161 & -0.020 & 0.546 & 0.444 & 0.534 & & 0.390 & 0.092 \\
\hline \multirow{2}{*}{$\begin{array}{l}\text { School } \\
\text { environment }\end{array}$} & 1 & 0.319 & 0.410 & 0.376 & 0.142 & 0.362 & 0.492 & 0.346 & 0.459 & & 0.293 \\
\hline & II & 0.442 & 0.559 & 0.223 & 0.028 & 0.342 & 0.594 & 0.529 & 0.390 & & -0.227 \\
\hline \multirow{2}{*}{$\begin{array}{l}\text { Social } \\
\text { acceptance }\end{array}$} & 1 & 0.343 & 0.271 & 0.308 & 0.309 & 0.242 & 0.335 & 0.221 & 0.224 & 0.293 & \\
\hline & II & 0.003 & 0.043 & 0.367 & 0.021 & 0.059 & -0.023 & -0.052 & 0.092 & -0.227 & \\
\hline
\end{tabular}

can be considered a multilevel concept, representing the result of mutual interaction of all physiological, psychological, and social factors influencing health. Measuring health-related quality of life, one may be interested in measurement at different levels and of various content. Different measurement tools will be needed to reach different aims $[11,12]$.

In the authors' research with the KIDSCREEN-52 questionnaire, a difference was observed in the health-related quality of life of girls with menstruation disorders (group I) and girls without health and development disorders (group II). The presented research results concern representative groups of girls during adolescence and, as mentioned, from environments different in terms of origin. In group I, the girls obtained lower results in all dimensions of healthrelated quality of life in comparison to the girls from group II. However, with age, those girls assessed their satisfaction with life more positively in individual dimensions of the KIDSCREEN-52 questionnaire. The girls from group I from urban and rural environ- ments did not perceive their health and well-being in positive categories. Meanwhile, most of the girls from group II assessed their health as good and very good, did not feel subjective ailments, and were happy with their current lives $(p<0.001)$.

So far, research on the quality of life has been popular in the medical sciences. Presently, the mission of health promotion recommended by the WHO and directed towards children is to support actions aimed at optimal general ranges of the norm of reactions in personal life and health. Multi-directional actions in the field of health promotion, as well as research conducted as part of the health sciences domain, where research on the health-related quality of life of children and adolescents is presently preferred, are an important element in shaping responsiveness and defences. That is why, until now, the quality of life of children and adolescents was assessed using the HBSC questionnaire. However, if one wishes to fully relate the quality of life of children and adolescents, one must take into consideration the low possibilities 
for comparison of research conducted with the use of the KIDSCREEN questionnaire from 2003 [13].

In the pilot research of Mazur (2003) on boys and girls aged 8-18 years, the participants assessed their material situation and school environment as the worst. The mean indexes of the quality of life in the dimension of financial resources, on the other hand, show the highest differentiation. The highest index values were obtained for the dimension of social acceptance, which means cases of exposure to unpleasantness from other schoolchildren were rare. The dimension of mental health, measured by moods and emotions, was also assessed as positive, which indicates no escalation of negative emotional states. The dimension of mental health concerning positive states transpired to be far worse. Girls during puberty show a more negative assessment of health-related quality of life in the dimensions of physical health, moods and emotions, self-perception, and independence and a more positive assessment of the health-related quality of life in the dimensions of contact with peers and the school environment. Girls aged 13-14 years assessed their health in the most positive way. The dimension of social acceptance was the sole exception, where mean indexes of the quality of life increased with age, which is connected with a lesser risk of unpleasantness from other schoolchildren [14]. Similarly, in our own research, girls with menstruation disorders assessed their quality of life more negatively in the following dimensions: physical health, moods and emotions, self-perception, and independence.

The research conducted on a healthy population and its results coincide with the results of the authors' research on girls from group II. There was, however, no material for comparison when it comes to the KIDSCREEN-52 results for girls with menstruation disorders.

The girls surveyed in study were in the phase of puberty. Menarche occurred in the participants between the ages of 10 and 15 years. Among the girls who matured earlier (menarche at the age of 11 years or earlier), a more negative assessment of the state of health was noted and a more frequent occurrence of negative emotional states observed, in comparison to their peers with normal or later puberty. Negative behaviours towards their own health and well-being (with reduced health-related quality of life) were noted among the girls (group I) with menstruation disorders, both reaching puberty early and late.

Michel, Bisegger, Fuhr, and Abel in their research stated that the quality of life of children and adolescents is different in European countries. Assuming the innate influence of cultural and socio-economic factors of the countries, they assessed the subjective perception of health and well-being of young people. UNICEFs report on the well-being of children and adolescents in wealthy countries provides a scale for comparison in 21 European countries in the following six aspects: material well-being, health and security, educational welfare, relations in the family and with peers, behaviours and risks, and subjective well-being. The mean rank indicates a more negative assessment of the health-related quality of life in girls living in the following countries: Poland, the Czech Republic, Hungary, the United Kingdom, Austria, and France; contrary to Holland, Spain, and Switzerland. In regard to age, it was indicated that in 12 European countries younger girls showed better values of health-related quality of life than the older adolescents. The differences between countries in quality of life indicate the significance of the national context for health and welfare of children and adolescents [15].

One should remember that any neglect in the socalled sensitive periods of development, puberty included, will affect the state of health and condition of the young women in adulthood, when playing a procreative role in the future. The attitude of an individual regarding their well-being and quality of life, regardless of the clinical image of their body, may be important for therapeutic decisions and may be an indication for unobserved medical or other non-health needs, and consequently may affect their health state in adulthood and that of future generations.

\section{Conclusions}

Taking into account variables such as age and the living environment, it was stated that younger girls (13-14 years) from groups I and II generally perceived their health as worse. Whereas with age in both groups (15-16 years) a greater percentage of respondents perceived themselves in a positive way, which resulted in higher self-assessment in health. The period of adolescence is extremely difficult for young people, and therefore adolescents need supporting adults who are aware of such problems, including parents, teachers, and school nurses. Special attention should be focused on the health education of young people, so they can adopt healthy lifestyles, which, when developed in youth will result in healthy adults who will have healthy children.

\section{Conflict of interest}

The authors declare no conflict of interest.

\section{References}

1. Lalonde M. A new perspective on the health of Canadians. A Working Document, Ottawa 2000.

2. Narodowy Program Zdrowia 1996-2006. Warszawa 1996.

3. Nowe impulsy dla młodzieży europejskiej. Biała Księga Komisji Europejskiej. ITE, Radom 2003.

4. Nowak-Starz G. Rozwój i zagrożenia zdrowia populacji w wieku rozwojowym w okresie przemian społeczno-ekonomicznych w Polsce (Development and health threats of the youth population during socio-economic changes in Poland). Wszechnica Świętokrzyska, Kielce 2008 . 
5. Robitail S, Simeon MC, Erhart M, Revens-Sieberer U, Bruil J, Auquier P; the European KIDSCREEN Group. Validation of the European proxy KIDSCREEN-52 pilot test health related quality of life questionnaire: first results. J Adolesc Health 2006; 39: 596.e1-10.

6. The KIDSCREEN Group Europe. The KIDSCREEN Questionnaires. Quality of life questionnaires of children and adolescent. Handbook. Pabst Science Publishers, Lengerich Germany 2006.

7. Swarr AE, Richards M. Longitudinal effects of adolescent girls pubertal development, perception of pubertal timing, and parental relation on eating problems. Develop Psychol 2000; 32: 636-46.

8. Haugland S. Subjective health complains in adolescence. A cross-national comparison of prevalence and dimensionality. Eur J Public Health 2001; 11: 4-10.

9. Woynarowska B. Międzynarodowe badania nad zachowaniami zdrowotnymi młodzieży szkolnej. Zdrowie Publiczne 2002; 112: 391-5.

10. Woynarowska B, Jodkowska M, Oblacińska A. Samoocena zdrowia i obrazu własnego ciała u młodzieży szkolnej w Polsce. Pediatr Pol 2007; 75: 25-34.

11. Woynarowska B, Pułtorak M, Wojciechowska A. Zachowania zdrowotne i postrzeganie własnego zdrowia przez młodzieży w wieku 11-16 lat w Polsce. Kultura Fizyczna 2007; 7-8: 11-12.

12. Spilker B. Introduction. In: Quality of Life and Pharmacoeconomics in Clinical Trials. Spilker B (ed.). Philadelphia, Lippincott-Raven, 1996.

13. Mazur J (ed). Społeczne determinanty zdrowia młodzieży szkolnej. Raport z badań HBSC 2010. Zakład Ochrony i Promocji Zdrowia Dzieci i Młodzieży, Instytut Matki i Dziecka, Warsaw 2011.

14. Mazur J. Analiza środowiska psychospołecznego szkoły i przystosowania szkolnego uczniów gimnazjów za pomocą wskaźników sumarycznych. In: Środowisko psychospołeczne szkoły i przystosowanie szkolne a zdrowie i zachowania zdrowotne uczniów w Polsce. Woynarowska B (ed.). Wydział Pedagogiczny UW, Instytut Matki i Dziecka, Warsaw 2003; 41-84.

15. Michel G, Bisegger C, Fuhr DC, Abel T; KIDSCREEN group. Age and gender differences in health-related quality of life of children and adolescents in Europe: a multilevel analysis. Qual Life Resh 2009; 9: 1147-57.

\section{Address for correspondence:}

Prof. Grażyna Nowak-Starz MD, PhD

Department of Developmental Age Research Institute of Public Health

Faculty of Health Sciences

Jan Kochanowski University

al. IX Wieków Kielc 19, 25-517 Kielce, Poland

Phone: +48 600433734

E-mail: gnowakstarz@wp.pl 